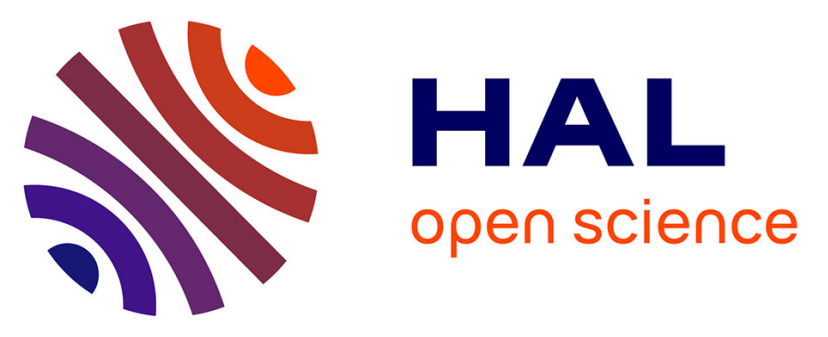

\title{
Energetic valorization of ammonium resulting from nitrate electrochemical reduction-Feasibility of biohydrogen production
}

Rawa Abdallah, Abdeltif Amrane, Hayet Djelal, Samir Taha, Florence Fourcade, Thierry Labasque, Florence Geneste, Didier Floner

\section{To cite this version:}

Rawa Abdallah, Abdeltif Amrane, Hayet Djelal, Samir Taha, Florence Fourcade, et al.. Energetic valorization of ammonium resulting from nitrate electrochemical reduction-Feasibility of biohydrogen production. Biochemical Engineering Journal, 2015, 94, pp.145 - 152. 10.1016/j.bej.2014.11.019 . insu-01112001

\section{HAL Id: insu-01112001 \\ https://hal-insu.archives-ouvertes.fr/insu-01112001}

Submitted on 2 Feb 2015

HAL is a multi-disciplinary open access archive for the deposit and dissemination of scientific research documents, whether they are published or not. The documents may come from teaching and research institutions in France or abroad, or from public or private research centers.
L'archive ouverte pluridisciplinaire HAL, est destinée au dépôt et à la diffusion de documents scientifiques de niveau recherche, publiés ou non, émanant des établissements d'enseignement et de recherche français ou étrangers, des laboratoires publics ou privés. 


\title{
Energetic valorization of ammonium resulting from nitrate electrochemical reduction - Feasibility of biohydrogen production
}

\author{
Rawa Abdallah ${ }^{1,2,6^{*}}$, Abdeltif Amrane ${ }^{3,6}$, Hayet Djelal ${ }^{4,6}$, Samir Taha $^{2}$, Florence \\ Fourcade $^{3,6}$, Thierry Labasque ${ }^{5,6}$, Florence Geneste ${ }^{1,6}$, Didier Floner ${ }^{1,6}$ \\ ${ }^{1}$ Université de Rennes 1, CNRS, UMR 6226, Equipe Matière Condensée et Systèmes \\ Electroactifs, Campus de Beaulieu, 35042 Rennes cedex, France.
}

${ }^{2}$ Université Libanaise, EDST, Centre Azm pour la Recherche en Biotechnologie et ses Applications, LBA3B, Rue El Mitein, Tripoli, Liban.

${ }^{3}$ Ecole Nationale Supérieure de Chimie de Rennes, Université de Rennes 1, CNRS, UMR 6226, 11 allée de Beaulieu, CS 50837, 35708 Rennes cedex 7, France.

${ }^{4}$ Ecole des Métiers de l'Environnement, Campus de Ker Lann, 35170 Bruz, France

${ }^{5}$ Géosciences Rennes-OSUR, UMR CNRS 6118, université de Rennes 1, France

${ }^{6}$ Université Européenne de Bretagne, 5 boulevard Laënnec, 35000 Rennes, France.

*Corresponding author. Tel: +3302 232350 10; fax: +33 0223235967 .

E-mail address: rawa.abdallah@univ-rennes1.fr (R. Abdallah)

Highlights

The feasibility of coupling electrochemical and biological processes to treat concentrated nitrate solutions was examined. 
$\bullet$ $\mathrm{NH}_{4}{ }^{+}$was shown.

Selective and quantitative electroreduction of $\mathrm{NO}_{3}^{-}$to

- The produced $\mathrm{NH}_{4}{ }^{+}$was then used as a nitrogen source in anaerobic batch culture of heat treated activated sludge.

- $\quad$ Complete assimilation of the obtained $\mathrm{NH}_{4}{ }^{+}$with production of an acceptable $\mathrm{H}_{2}$ yield $\left(0.35 \mathrm{~mol} \mathrm{H}_{2} / \mathrm{mol}\right.$ glucose $)$ was recorded.

Environmentally friendly coupled process was developed.

\section{Abstract}

The main objective of this work was to examine the feasibility of coupling electrochemical and biological processes to destroy nitrate ions $\left(\mathrm{NO}_{3}{ }^{-}\right)$while producing biohydrogen. In this integrated process $\mathrm{NO}_{3}{ }^{-}$was firstly converted to ammonium using an electrochemical flow cell. After only one pass of concentrated nitrate solutions (3 $\mathrm{g}$ $\mathrm{NO}_{3}{ }^{-} \mathrm{L}^{-1}$ ) through the flow cell, ammonium ions selectivity of $98.8 \%$, corresponding to $0.86 \mathrm{~g} \mathrm{NH}_{4}{ }^{+} \mathrm{L}^{-1}$ was recorded. The obtained ammonium solution was then tested as a nitrogen source to produce $\mathrm{H}_{2}$ in a batch system involving heat-treated aerobic activated sludge.

In the optimal conditions corresponding to $\mathrm{pH} 5.5$ and initial glucose concentration of $15 \mathrm{~g} \mathrm{~L}^{-1}$, consumption yields were $97 \%$ and $82 \%$ for ammonium and glucose, leading to $\mathrm{H}_{2}$ yield of $0.35 \mathrm{~mol} \mathrm{H}_{2} \mathrm{~mol}^{-1}$ glucose consumed. The $\mathrm{H}_{2}$ production was associated with acetic/ butyric acids type fermentation. Obtained biogas contains only $\mathrm{H}_{2}$ and $\mathrm{CO}_{2}$ and was free of methane, hydrogen sulphide and nitrous oxide. Therefore, the targeted 
objectives were achieved since on the one hand selective and quantitative conversion of $\mathrm{NO}_{3}{ }^{-}$to $\mathrm{NH}_{4}{ }^{+}$was shown and on the other hand the obtained $\mathrm{NH}_{4}{ }^{+}$was completely assimilated by activated sludge with the production of biohydrogen, a clean energy carrier.

Keywords: Nitrate electrochemical reduction; Ammonium; Heat treated activated sludge; Dark fermentation; Biohydrogen production; Coupled process

\section{Introduction}

Nitrate contamination of groundwater, lakes or rivers has attracted increasing global concern due to several impacts on human health (e.g., gastrointestinal cancer, liver damage) and aquatic ecosystems (e.g., eutrophication) [1]. In this respect, the removal of $\mathrm{NO}_{3}{ }^{-}$has been extensively investigated over the last few decades.

Many processes are currently used to eliminate $\mathrm{NO}_{3}{ }^{-}$ions from contaminated waters. Nevertheless, there are some disadvantages with these methods that limit their utility for large scale application:

(1) Physicochemical processes such as ion exchange, reverse osmosis and electrodialysis are costly and not destructive [2]. Hence these methods lead to concentrated effluents of nitrates $\left(\geq 3 \mathrm{~g} \mathrm{~L}^{-1}\right)[3]$ that are very difficult to treat.

(2) Biological denitrification, which mainly involves facultative anaerobes, leading to the need for anoxic conditions in order to reduce nitrate to nitrite $\left(\mathrm{NO}_{2}{ }^{-}\right)$and subsequently to nitrogen gas $\left(\mathrm{N}_{2}\right)$, according to the following sequence [4]:

$$
\mathrm{NO}_{3}{ }^{-} \rightarrow \mathrm{NO}_{2}{ }^{-} \rightarrow \mathrm{NO}(\mathrm{g}) \rightarrow \mathrm{N}_{2} \mathrm{O}(\mathrm{g}) \rightarrow \mathrm{N}_{2}(\mathrm{~g})
$$


However, the knowledge about biological denitrification of industrial wastewaters containing high nitrate concentration still limited. There are two principal problems in the biodenitrification of high $\mathrm{NO}_{3}{ }^{-}$wastewater. First, this process is slow and lasts many days particularly for high strength nitrate waste $[5,6]$. Secondly, nitrate elimination can be hampered by the accumulation of nitrite during the process, because $\mathrm{NO}_{2}{ }^{-}$is an inhibitor of microbial growth [6].

(3) Electrochemical reduction of $\mathrm{NO}_{3}{ }^{-}$which receives, in analytical scale, more and more attention due to its advantages, namely its ease of use, low investment costs and environmental friendliness particularly if the resulting product is $\mathrm{N}_{2}$ gas [7]. However, the main problem in this approach is that the transformation of $\mathrm{NO}_{3}{ }^{-}$to nitrogen is a difficult reaction since both the rate and the selectivity of the reduction are usually low $[8]$.

One promising and attractive way of treatment which can lead to interesting solutions consists in the coupling of an electrochemical process to a and biological treatment [9]. For this purpose, on the one hand, according to the literature, nitrate electroreduction has been widely studied using several electrodes materials such as $\mathrm{Pt}, \mathrm{Pb}, \mathrm{Ni}, \mathrm{Zn}, \mathrm{Pd}$, $\mathrm{Cu}, \mathrm{Ag}$ and $\mathrm{Au}$. Among these materials, Copper $(\mathrm{Cu})$ is known to exhibit the highest electrocatalytic activity for the nitrate reduction by mainly producing ammonia as final product [10]. On the other hand, many researchers focused on the use of inorganic ammonium $\left(\mathrm{NH}_{4}{ }^{+}\right)$as a potential nitrogen source for biological hydrogen production [11-15]; and the use of cheap inorganic nitrogen source appears relevant from an economical point of view, contrarily to organic nitrogen sources such as yeast extract $[16,17]$ and polypepton $[18,19]$ which are often more expensive. For these reasons, from an environmental and economical point of view, an electroreduction of nitrate to 
$\mathrm{NH}_{4}{ }^{+}$over copper cathode can be considered as an attractive way, since it allows not only pollutant treatment, nitrate, but also possible valorization of the treated effluent. Therefore, the combination of nitrate electrochemical reduction and the use of the obtained ammonium solutions as a nitrogen source in a microbial culture is proposed in this study, for the first time to our knowledge.

Hydrogen is considered as an ideal and clean energy carrier owing to its high energy content and non-polluting nature, since its combustion product is water [20]. $\mathrm{H}_{2}$ may be produced by various processes such as thermocatalytic reformation of hydrogen rich substrates, electrolysis of $\mathrm{H}_{2} \mathrm{O}$, as well as various biological processes [21,22]. Among these methods biohydrogen production by microorganisms is regarded as one of the most promising alternatives for sustainable production due to its potential for low-cost, inexhaustible and renewable source of clean energy [20].

Biohydrogen production under anaerobic conditions can be classified into two different categories according to the type of microorganisms employed: dark-fermentative hydrogen production and photofermentative hydrogen production [23]. Darkfermentative has more advantages than photofermentation hydrogen production, including high hydrogen production rate, energy savings, lower maintenance costs, simple process control and broad spectrum of feedstock [24]. Let's add its applicability to different types of wastewaters and organic wastes from industrial processes [25], reducing furthermore waste disposal problems.

Fermentative hydrogen production processes via mixed cultures are more practical than those using pure cultures, because the former are easier to control and simpler to operate [26]. At present, the microbial consortium present in anaerobic sludge are the most widely used as inoculum for fermentative hydrogen production [27-32]. But according 
to our knowledge, up to now only few studies in the literature focused on the capacity of aerobic activated sludge for biohydrogen production [33,34]. However, it should be noted that such inoculum has the advantage of containing mostly facultative anaerobic hydrogen-producing bacteria which are very robust and not inhibited by the presence of oxygen trace who accidentally enter in the bioreactor; these facultative anaerobes are then able to install the anaerobic conditions conducive to hydrogen production. Moreover aerobic activated sludge is relatively more available than anaerobic one.

Whilst biological process is considered as a promising approach for hydrogen production, the high production cost is still a key issue for projecting this technology to an industrial-scale. Nitrogen and carbon feedstock represents $30-40 \%$ total costs of fermentative hydrogen production [35]. Thus, finding an alternative nitrogen source as substitute for commercial products to reduce the total costs of biohydrogen production would be interesting. For this purpose, the main objective of this report is the energetic valorization of ammonium solution resulting from nitrate electrochemical treatment. To achieve this goal, a flow electrochemical process was first developed, allowing a selective and quantitative transformation of concentrated nitrate solutions into ammonium. In a second step, the obtained ammonium solution was used as a nitrogen source to evaluate the feasibility of biohydrogen production by dark fermentation.

\section{Materials and Methods}

\subsection{Electrochemical nitrates pretreatment}

One liter of synthetic nitrate solutions of $3 \mathrm{~g} \mathrm{NO}_{3} \mathrm{~L}^{-1}$ was prepared by dissolving potassium nitrate crystals $\left(\mathrm{KNO}_{3}\right)$ in phosphoric acid $\left(\mathrm{H}_{3} \mathrm{PO}_{4} 10^{-2} \mathrm{M}\right)$. The $\mathrm{pH}$ of the electrolyte solution was adjusted to $\mathrm{pH} 1.1$ using sulfuric acid $96 \%$. This high nitrate 
concentration was chosen to be similar to the real effluents obtained after ion exchange treatment process of nitrate-contaminated drinking water $[3,36]$.

Nitrate electrochemical reduction was carried out at room temperature in a single pass through a home-made flow cell presented in Fig.1.

Figure 1

The working electrode was a copper porous material $(5.6 \mathrm{~cm}$ diameter and $0.3 \mathrm{~cm}$ thickness) prepared as previously described [37]. Graphite felt (RVG 4000) used as metal electrodeposition support was supplied by MERSEN (Paris La Defense, France). Its specific area, measured by the BET method was $0.7 \mathrm{~m}^{2} \mathrm{~g}^{-1}$, its density was $0.088 \mathrm{~g}$ $\mathrm{cm}^{-3}$ and its carbon yield was $99.9 \%$. The homogeneity of the copper coating obtained after metal electrodeposition was checked by scanning electron microscopy (SEM) (Fig.2 (a) and 2(b)).

Figure 2

To ensure a good homogeneity of the potential distribution in the three dimensional working electrode, the $\mathrm{Cu}$ modified graphite felt was located between two counterelectrodes made of fine platinum grids. The electrical contact with the working electrode was performed with a copper wire. The $\mathrm{NO}_{3}{ }^{-}$solutions percolated the porous electrode at a constant flow rate of $2 \mathrm{~mL} \mathrm{~min}^{-1}$ monitored by a Gilson minipuls 2 peristaltic pumps (Middleton, WI, USA). The current intensity was generated by a 
home-made power supply (30 V/3 A). The cell was thoroughly rinsed with distilled water before and after each experiment.

The applied current intensity (A) was calculated according to the following relation:

$\mathrm{i}(\mathrm{A})=\left[\mathrm{NO}_{3}{ }^{-}\right]_{\mathrm{t}=0} \times \mathrm{d} \times\left(10^{-3} / 60\right) \times \mathrm{n} \times \mathrm{F}$

where $\left[\mathrm{NO}_{3}{ }^{-}\right]_{\mathrm{t}=0}$ is the initial nitrate concentration $\left(\mathrm{mol} \mathrm{L}^{-1}\right), \mathrm{d}$ is the flow rate $\left(\mathrm{mL} \mathrm{min}^{-}\right.$ $\left.{ }^{1}\right), \mathrm{F}$ is the Faraday's constant $(96500 \mathrm{C})$ and $\mathrm{n}$ is the number of exchanged electrons, $8 \mathrm{e}^{-}$ , for the conversion of nitrate to ammonium.

The performance of the flow cell was evaluated from the electrochemical conversion of nitrate into ammonium after one pass through the flow cell, considering the following parameters: the chemical yield of ammonium formation $\left(\% \mathrm{X}_{\mathrm{NH} 4+}\right)$ (Eq. 2) and the selectivity based on the ammonium yield (\% $\left.\mathrm{S}_{\mathrm{NH} 4+}\right)$ (Eq. 3).

$\% \mathrm{X}_{\mathrm{NH} 4+}=\left(\left[\mathrm{NH}_{4}^{+}\right]_{\mathrm{t}} \times 100\right) /\left[\mathrm{NO}_{3}{ }^{-}\right]_{\mathrm{t}=0}$

$\% \mathrm{~S}_{\mathrm{NH} 4+}=\left(\left[\mathrm{NH}_{4}^{+}\right]_{\mathrm{t}} \times 100\right) /\left(\left[\mathrm{NO}_{3}{ }^{-}\right]_{\mathrm{t}=0}-\left[\mathrm{NO}_{3}{ }^{-}\right]_{\mathrm{t}}\right)$

where $[\mathrm{X}]_{\mathrm{t}=0}$ and $[\mathrm{X}]_{\mathrm{t}}$ are the concentrations of $\mathrm{NH}_{4}{ }^{+}$or $\mathrm{NO}_{3}{ }^{-}$in solution at initial time $\mathrm{t}_{0}$ and a given time $\mathrm{t}(\mathrm{s})$. All the concentrations are in $\mathrm{mol} \mathrm{L}^{-1}$.

After only one pass through the electrochemical flow cell, the solutions were collected for subsequent biohydrogen production experiments.

\subsection{Culture and Medium}

Biological hydrogen production was carried out in anaerobic conditions, using activated sludge collected from the aeration tank of a local wastewater treatment plant (Beaurade, Rennes, France). Prior to use, activated sludge was first washed three times with tap water and three times with ultrapure water [38]. After each washing, sludge was centrifuged at $4000 \mathrm{rpm}$ for $10 \mathrm{~min}$ (Jouan, Thermo Fisher Scientifics, Saint Herblain, 
France), and the supernatant was then separated from the sludge to remove any residual carbon or mineral source. Just before the last centrifugation the cells were sieved to remove sand, stones, and other coarse matters. In order to inactivate hydrogenotrophic methanogens and to enrich $\mathrm{H}_{2}$-producing bacteria the sludge was heat-treated at $102^{\circ} \mathrm{C}$ for $90 \mathrm{~min}$ before use.

The reactors were inoculated with the heat-treated sludge $\left(4 \mathrm{~g} \mathrm{~L}^{-1}\right)$ and grown on glucose used as a carbon source in a mineral salt medium (MSM). The MSM was buffered to a $\mathrm{pH}$ of 5.5 or 6.2 , using $0.07 \mathrm{M}$ of 2-(N-morpholino) ethanesulfonic acid monohydrate (MES) [14]. These $\mathrm{pH}$ values were chosen, since they were close to the optimal values for hydrogen production and since they can be achieved with MES, an inexpensive and nontoxic buffer [14,39]. The MSM consisted of the following nutrients (per liter of medium): $360 \mathrm{mg} \mathrm{MgSO}_{4} \cdot 7 \mathrm{H}_{2} \mathrm{O}, 66 \mathrm{mg} \mathrm{CaCl} 2.2 \mathrm{H}_{2} \mathrm{O}, 48 \mathrm{mg} \mathrm{NiCl} 2.6 \mathrm{H}_{2} \mathrm{O}$, $50 \mathrm{mg} \mathrm{FeCl}$, $21 \mathrm{mg} \mathrm{CoCl} \cdot 6 \mathrm{H}_{2} \mathrm{O}, 23 \mathrm{mg} \mathrm{ZnCl}_{2}, 30 \mathrm{mg} \mathrm{MnCl}_{2} \cdot 4 \mathrm{H}_{2} \mathrm{O}, 10 \mathrm{mg}$ $\mathrm{CuCl}_{2} \cdot 2 \mathrm{H}_{2} \mathrm{O}, 175 \mathrm{mg} \mathrm{K} \mathrm{HPO}_{2}$ and $175 \mathrm{mg} \mathrm{KH} \mathrm{KHO}_{4}$.

Ammonium source was $\mathrm{NH}_{4} \mathrm{Cl}$ added separately to each reactor at a concentration of $0.87 \mathrm{~g} \mathrm{NH}_{4}^{+} / \mathrm{L}$ for the synthetic medium, or using the electrolyzed solution collected after electrochemical treatment of the nitrate solution. The chosen ammonium concentration, $0.87 \mathrm{~g} \mathrm{NH}_{4}^{+} \mathrm{L}^{-1}$, corresponded to the theoretical maximum amount of $\mathrm{NH}_{4}{ }^{+}$which can be obtained by electrochemical reduction of the chosen nitrate solution

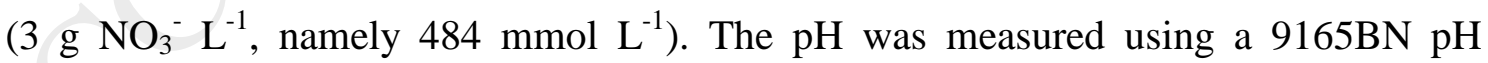
electrode connected to an Orion-828 pH Analyzer (Orion Research Inc., Beverly, MA, USA).

Batch experiments were conducted using $125 \mathrm{~mL}$ glass bottles with a working volume of $100 \mathrm{~mL}$. The bottles were flushed with nitrogen for $5 \mathrm{~min}$ to provide anaerobic 
conditions, capped with a rubber stopper to allow sampling with a syringe and placed in a shaker at $180 \mathrm{rpm}$. Experiments were performed at a constant temperature $\left(37^{\circ} \mathrm{C} \pm 1\right)$. To take into account a possible effect of nutrients coming from the solubilization of sewage sludge by thermal pretreatment, one inoculated additional bottle containing the medium without addition of the nitrogen and glucose sources was used as a control test for biohydrogen production in the absence of added carbon and nitrogen substrates. All tests (except the biotic control) were run in duplicates.

In order to find the optimal conditions for biohydrogen production, initial $\mathrm{pH}(\mathrm{pH} 5.5$ and 6.2) and glucose concentration $\left(5,10,15,20,30 \mathrm{~g} \mathrm{~L}^{-1}\right)$ were evaluated using synthetic solution of ammonium $\left(0.87 \mathrm{~g} \mathrm{NH}_{4}{ }^{+} \mathrm{L}^{-1}\right)$. The obtained optimal $\mathrm{pH}$ and glucose concentration were used afterwards to produce biohydrogen using the experimental $\mathrm{NH}_{4}{ }^{+}$-containing solution collected after electrolysis of $3 \mathrm{~g} \mathrm{NO}_{3}{ }^{-} \mathrm{L}^{-1}$.

\subsection{Analytical methods}

$\mathrm{NO}_{3}{ }^{-}$and $\mathrm{NO}_{2}{ }^{-}$ions were analyzed using ion chromatography (Dionex 120) equipped with a Dionex on Pac AS18A Anion Exchange column and a chemical suppressor (ASR 300 -ultra $4 \mathrm{~mm}$ ), using $8 \mathrm{KOH} 1 \mathrm{M}$ as eluent at a flow rate of $1.04 \mathrm{~mL} \mathrm{~min}^{-1}$. Produced and residual $\mathrm{NH}_{4}{ }^{+}$concentrations obtained after electrolysis and after biohydrogen production were determined by visible spectroscopy (Nessler-Folin reagent method) on an UV-vis spectrophotometer (Cary-1E, Varian), respectively.

The amount of different biogas $\left(\mathrm{H}_{2}, \mathrm{CO}_{2}, \mathrm{~N}_{2} \mathrm{O}, \mathrm{CH}_{4}\right.$, and $\left.\mathrm{H}_{2} \mathrm{~S}\right)$ were obtained by gas analyses on a $\mu \mathrm{GC} / \mathrm{TCD}$ (Agilent Micro GC3000, SRA Instruments). Water in samples was equilibrated with the produced biogas at atmospheric pressure and ambient temperature $\left(20^{\circ} \mathrm{C}\right)$. For gas chromatography analysis, pure helium (6.0 quality) was 
used as gas phase and the pressure through the columns was fixed at 40 psi. $\mathrm{H}_{2}, \mathrm{CH}_{4}$ and $\mathrm{H}_{2} \mathrm{~S}$ were analyzed on molecular sieve $5 \AA$ column $(30 \mathrm{~m})$ and $\mathrm{CO}_{2}$ and $\mathrm{N}_{2} \mathrm{O}$ were analyzed on PoraplotQ column (10m). Columns were heated at $30{ }^{\circ} \mathrm{C}$. Retention times were between 0.2 and $5 \mathrm{~min}$ for all compounds. Calibration was realized with atmospheric air, and calibrated air standard (Air liquid): $150 \mathrm{ppm}$ and $2 \%$ for $\mathrm{H}_{2}, 200$ ppm for $\mathrm{H}_{2} \mathrm{~S}, 250 \mathrm{ppm}$ for $\mathrm{N}_{2} \mathrm{O}$ and $500 \mathrm{ppm}$ for $\mathrm{CO}_{2}$ and $\mathrm{CH}_{4}$. Analytical precision for all compounds was around $2 \%$ at calibration level and near $10 \%$ below 20 ppm. Detection limit was around 2 ppm for all compounds.

Produced organic acids and alcohols were analyzed in the aqueous phase using a gas chromatograph (Focus GC Thermo) equipped with a flame ionization detector (FID). The chromatographic column was a $25 \mathrm{~m}$ long Chrompac ${ }^{\mathrm{TM}}$ capillary column FFAP$\mathrm{CB}$, specially adapted to the separation of volatile fatty acids (VFA). Before analysis, liquid samples were filtered through a $0.2 \mu \mathrm{m}$ pore-diameter filters (Whatman, Florham Park, NJ.).

Residual glucose in the effluent was analyzed using a Shimadzu LC-20AD liquid chromatograph equipped with an ions exclusion column HPX-87H $(300 \times 7.8 \mathrm{~mm}$; BioRad, Hercules, CA, USA), maintained at $45^{\circ} \mathrm{C}$ (Oven CrocoCil TM, Cluzeau-Info-labo, Ste Foy La Grande, France). $0.01 \mathrm{~N} \mathrm{H}_{2} \mathrm{SO}_{4}$ was used as mobile phase. The flow rate of the eluant was monitored at $0.7 \mathrm{~mL} \mathrm{~min}^{-1}$ (Waters pump, Milford, MA, USA).

\section{Results and Discussion}

\subsection{Biohydrogen production using synthetic $\mathrm{NH}_{4}{ }^{+}$solution}

Owing to its greater availability if compared to anaerobic activated sludge which is often used for biohydrogen production, aerobic activated sludge was considered to 
perform these first tests. The proper conditions (optimal glucose concentration and $\mathrm{pH}$ ) for $\mathrm{H}_{2}$ production were first determined. To achieve this goal, synthetic wastewater containing $0.87 \mathrm{~g} \mathrm{~L}^{-1}$ of $\mathrm{NH}_{4}{ }^{+}$was treated at two $\mathrm{pH}$ values (5.5 and 6.2) and glucose concentrations varying from 5 to $30 \mathrm{~g} \mathrm{~L}^{-1}$; the corresponding results are displayed below.

\subsubsection{Glucose consumption, Hydrogen yield and metabolites}

Hydrogen yields were calculated for all batch reactors based on the amount of glucose consumed and the amount of hydrogen produced. The result are displayed in Fig.3.

Figure 3

Fig.3(a) shows that at $\mathrm{pH} 5.5 \mathrm{H}_{2}$ yield, increased with glucose concentration from 0.19 $\mathrm{H}_{2} \mathrm{~mol}^{-1}$ glucose consumed at $5 \mathrm{~g} \mathrm{~L}^{-1}$ to reach an optimal hydrogen production of $0.3 \mathrm{~mol} \mathrm{H}_{2}$ mol $^{-1}$ glucose consumed glucose at $15 \mathrm{~g} \mathrm{~L}^{-1}$. Further increase of the glucose amount decreased the $\mathrm{H}_{2}$ yield, which remained approximately constant at $0.23 \mathrm{~mol} \mathrm{H}_{2} \mathrm{~mol}^{-1}$ glucose consumed beyond $15 \mathrm{~g} \mathrm{~L}^{-1}$. A similar optimal glucose concentration $\left(13.5 \mathrm{~g} \mathrm{~L}^{-1}\right)$ was reported by [12] in batch biohydrogen production study. The increase of the $\mathrm{H}_{2}$ yield Fig.3(a) should be most likely related to an insufficient availability of the carbon source at glucose concentrations below $15 \mathrm{~g} \mathrm{~L}^{-1}$. The increase of the initial glucose concentration from 5 to $20 \mathrm{~g} \mathrm{~L}^{-1}$ led to an increase of the amount of glucose assimilated by the microorganisms from $4.7 \mathrm{~g} \mathrm{~L}^{-1}$ to $10 \mathrm{~g} \mathrm{~L}^{-1}$, while above $20 \mathrm{~g} \mathrm{~L}^{-1}$, glucose consumption decreased to $3.8 \mathrm{~g} \mathrm{~L}^{-1}$, namely about $13 \%$ consumption yield (Fig.(3a)), as also the case for the $\mathrm{H}_{2}$ yield recorded at $\mathrm{pH}$ 5.5. 
Fig.3 (b) shows that at $\mathrm{pH}$ 6.2, the increase of the initial glucose concentration did not lead to an improvement of the $\mathrm{H}_{2}$ yield. Whatever the initial glucose concentration the hydrogen yield was nearly constant at $0.12 \mathrm{~mol} \mathrm{H}_{2} \mathrm{~mol}^{-1}$ glucose consumed. Regarding glucose consumption (Fig.3(b)), at initial glucose of $5 \mathrm{~g} \mathrm{~L}^{-1}$, the recorded glucose degradation amount was $4.98 \mathrm{~g} \mathrm{~L}^{-1}$ corresponding to a glucose conversion of $99.6 \%$. Beyond $5 \mathrm{~g} \mathrm{~L}^{-1}$, it increased to $8 \mathrm{~g} \mathrm{~L}^{-1}$ and remained nearly constant at this value. The decrease of biohydrogen production yield beyond a given glucose amount has also been reported in the literature. In their study on the effect of substrate concentration on biohydrogen production kinetics from food industry wastewater, [11] found that growth rates significantly decreased at high substrate concentrations. At $\mathrm{pH}$ 5.5, [40] also found a similar behavior, namely constant $\mathrm{H}_{2}$ production yields for an influent glucose concentration of 10 to $30 \mathrm{~g} \mathrm{~L}^{-1}$, while it decreased at $40 \mathrm{~g}$ glucose $\mathrm{L}^{-1}$; for these authors, high glucose concentrations promotes the generation of self-produced volatile acids, especially butyric and acetic acids, which have an inhibitory effect on biohydrogen production. It is in agreement with our observations, since for both $\mathrm{pHs}$ the amount of produced acetic acid increased with the initial glucose concentration (Table 1).

Table1

Accordingly, it is noteworthy that acetate buffer $\mathrm{pH} 5\left(\mathrm{CH}_{3} \mathrm{COOH} / \mathrm{CH}_{3} \mathrm{COO}^{-} 10^{-3} \mathrm{M}\right.$ $/ 10^{-3} \mathrm{M}$ ), which can also plays the role of the carbon source, cannot be considered owing to the inhibitory effect of acetic acid on biological hydrogen production, as experimentally confirmed (Table 2). 
Table 2

The profile of the metabolites present in the liquid phase under different feeding glucose concentration is presented in table 1 and shows that at $\mathrm{pH} 5.5$ the main soluble product was acetic acid followed by butyric acid. When $5 \mathrm{~g} \mathrm{~L}^{-1}$ glucose were added in the reactor the heat-treated aerobic activated sludge produced approximately $1499 \mathrm{mg} \mathrm{L}^{-1}$ ethanol but only low amounts of acetic and or butyric acids (Table 1). An increase of the initial glucose concentration from 10 to $30 \mathrm{~g} \mathrm{~L}^{-1}$ resulted in an increase of the production of acetic and butyric acids, while ethanol production decreased. This was indicative of $\mathrm{H}_{2}$ production favored process. In contrast, at $\mathrm{pH} 6.2$ (Table 1), whatever the initial glucose concentration ethanol followed by butyric acid were the two most abundant species in the effluent. This metabolite shift indicated that the increase of initial $\mathrm{pH}$ from 5.5 to 6.2 led to a switch from acetic / butyric acid to ethanol / butyric acid pathway, respectively. Low amounts of n-butanol, ethyl acetate and acetaldehyde were detected during all experiments. It is noteworthy that acetaldehyde is an intermediate of ethanol-producing metabolic pathway. This pathway does not produce $\mathrm{H}_{2}$ like the acetate and butyrate pathways do [41].

Concerning the $\mathrm{pH}$ effect, it should be mentioned the more pronounced impact on hydrogen production than on glucose consumption. $\mathrm{H}_{2}$ yields were always significantly higher at $\mathrm{pH} 5.5$ (Fig.3 (a)) if compared to $\mathrm{pH} 6.2$ (Fig.3 (b)). It was especially noticeable for the optimal glucose amount $\left(15 \mathrm{~g} \mathrm{~L}^{-1}\right)$ where similar amounts of glucose $\left(8 \mathrm{~g} \mathrm{~L}^{-1}\right)$ were assimilated, while hydrogen productions differed significantly. This $\mathrm{pH}$ effect should be most likely attributed to the hydrogenase specific activity, which is 
higher at $\mathrm{pH} 5.5$ than at $\mathrm{pH}$ 6.2. This clearly appears from the high production of ethanol recorded at $\mathrm{pH} 6.2$; such product associated with a zero- $\mathrm{H}_{2}$ pathways [42].

Accordingly, investigating the $\mathrm{pH}$ effect on biohydrogen production and hydrogenase activity in the range of $\mathrm{pH}$ values from 5 to 8 and in similar conditions than those considered in the present work $\left(37^{\circ} \mathrm{C}\right.$, glucose as carbon source and in batch mode). Xiao et al [15] found that hydrogenase activity decreased significantly with increasing culture $\mathrm{pH}$ and that weak acidic conditions favored hydrogen production. Maximum hydrogenase activity was obtained at $\mathrm{pH} 5$.

\subsubsection{Ammonium consumption and final $\mathrm{pH}$}

Fig.4 shows ammonium consumption yields in the range 39 to $52 \%$ for all experiments, showing the absence of nitrogen limitation of bacterial growth.

Figure 4

Final $\mathrm{pH}$ values obtained after 48 hours of batch culture (Fig.4) were similar, namely close to 3.4-3.5 and to 3.7-3.8 for initial $\mathrm{pH}$ values of 5.5 and 6.2 respectively. $\mathrm{pH}$ decrease can be attributed to the formation of acidic products, mainly acetic acid generated during the course of glucose dark fermentation (Table 1), in agreement with the literature [43].

\subsubsection{Biogas composition}


Micro GC analyses showed the absence of methane, $\mathrm{H}_{2} \mathrm{~S}$ (hydrogen competitor) and $\mathrm{N}_{2} \mathrm{O}$ formation throughout experiments including the biotic controls. However, contrarily to the control realized without the addition of nitrogen and glucose sources at both $\mathrm{pH}$ values, 5.5 and 6.2. The biogas comprised only $\mathrm{H}_{2}$ and $\mathrm{CO}_{2}$. At $\mathrm{pH} 5.5$ (Fig.5), the carbon dioxide content in the biogas followed an opposite trend to that of hydrogen.

Figure 5

However at $\mathrm{pH}$ 6.2, whatever the initial glucose concentration, the hydrogen and carbon dioxide contents were approximately constant at $23 \%$ and $77 \%$, respectively.

The absence of $\mathrm{CH}_{4}$ proved the efficiency of the heat-treatment method used to enrich $\mathrm{H}_{2}$-producing inocula from aerobic-mixed cultures. Indeed, the presence of hydrogen and the absence of methane can be explained by the fact that, during the enrichment, the $\mathrm{H}_{2}$-consuming hydrogenotrophic methanogens were inactivated or inhibited, whereas the $\mathrm{H}_{2}$-producing bacteria, e.g. clostridia, survived. Indeed, endospores from the latter bacteria are very resistant to heat and cannot be easily inactivated or inhibited even by harsh chemicals [44]. Besides, the absence of biohydrogen production in the biotic control indicated that no nutrient were solubilized during the thermal pretreatment of activated sludge.

3.2. Biohydrogen production using the $\mathrm{NH}_{4}{ }^{+}$solution resulting from $\mathrm{NO}_{3}{ }^{-}$ electroreduction 
The optimal conditions determined above, namely a glucose concentration of $15 \mathrm{~g} \mathrm{~L}^{-1}$ and $\mathrm{pH} 5.5$ were considered thereafter to produce biohydrogen using an ammonium solution resulting from the electroreduction of nitrate solutions $\left(3 \mathrm{~g} \mathrm{NO}_{3} \mathrm{~L}^{-1}\right)$.

Nitrate electrolysis were realized with $\mathrm{NO}_{3}{ }^{-}$solutions of $3 \mathrm{~g} \mathrm{~L}^{-1}$; this concentration has been chosen to be in similar conditions than real effluents obtained after a classical physicochemical denitrification of polluted waters [3]. Two supporting electrolytes were chosen to prepare $\mathrm{NO}_{3}{ }^{-}$solutions: (1) phosphate buffer $\left(\mathrm{H}_{2} \mathrm{PO}_{4}{ }^{-} / \mathrm{HPO}_{4}{ }^{2-} 310^{-3} \mathrm{M} / 310^{-3}\right.$ M) and (2) phosphoric acid $\left(10^{-2} \mathrm{M} \mathrm{H}_{3} \mathrm{PO}_{4}\right)$. It should be observed that such electrolytes were used to avoid the addition of a phosphorus source, needed for the subsequent microbial culture.

Experiments were performed under the optimal conditions determined in a previous study [37] namely a flow rate of $2 \mathrm{~mL} \mathrm{~min}^{-1}$ and a current intensity of (1.24 A) applied between the copper porous electrode and the counter electrodes (Fig.1). It is interesting to note that the consumed electric energy was $2.56 \mathrm{~kW}$.h / $\mathrm{kg} \mathrm{NO}_{3}{ }^{-}$, corresponding to an electricity price of $0.2 € / \mathrm{kg} \mathrm{NO}_{3}{ }^{-}$.

Nitrate electrochemical reduction occurs according to reaction 1. Reactions (1), (2) and (3) take place at the cathode and produce more hydroxyl anions than the protons formed at the anode (reaction 4). Consequently, the $\mathrm{pH}$ value should increase during electrolysis more or less strongly according to the chemical yield of nitrate reduction.

$$
\begin{array}{rll}
\mathrm{NO}_{3}^{-}+8 \mathrm{e}^{-}+7 \mathrm{H}_{2} \mathrm{O} & \rightleftharpoons & \mathrm{NH}_{4}^{+}+10 \mathrm{OH}^{-} \\
2 \mathrm{NO}_{3}^{-}+6 \mathrm{H}_{2} \mathrm{O}+10 \mathrm{e}^{-} & \rightleftharpoons \mathrm{N}_{2}+12 \mathrm{OH}^{-} \\
2 \mathrm{H}_{2} \mathrm{O}+2 \mathrm{e}^{-} & \rightleftharpoons \mathrm{H}_{2}+2 \mathrm{OH}^{-} \\
6 \mathrm{H}_{2} \mathrm{O} & \rightleftharpoons \mathrm{O}_{2}+4 \mathrm{H}_{3} \mathrm{O}^{+}+4 \mathrm{e}^{-}
\end{array}
$$

Owing to the high nitrate concentration this behavior may be amplified and hence a buffered solution was chosen as an electrolytic medium (phosphate buffer). After a 
single pass of the nitrate solution buffered to an initial $\mathrm{pH}$ of 7.2 through the flow cell a drastic increase of the outlet $\mathrm{pH}$ was observed, until $\mathrm{pH} 14$. To test the collected effluent for biohydrogen production, the $\mathrm{pH}$ was then adjusted to 5.5 using MES buffer and activated sludge culture was performed in the above conditions (see 2.2). However and unfortunately no hydrogen was produced after 48 hours incubation under these conditions. A slight corrosion of the copper cathode used for nitrate electroreduction occurred at such alkaline $\mathrm{pH}$ (14) and most likely accounted for this absence of hydrogen production. This corrosion process involved the formation of $\mathrm{Cu}\left(\mathrm{NH}_{3}\right)_{4}{ }^{2+}$ [45], enhancing therefore the amount of $\mathrm{Cu}^{2+}$ in the outlet effluent. Microorganisms requires copper at low concentrations as cofactors for matalloproteins and enzymes [46], but copper is also known to have a significant antibacterial activity, since above $150 \mu \mathrm{mol} \mathrm{L}^{-1}$ copper ions have a toxic effect on most microorganisms and inhibit bacterial growth [47]. Indeed, the mineral supplementation added in the culture medium has to contain only a small amount of $\mathrm{Cu}^{2+}\left(10 \mathrm{mg} \mathrm{L}^{-1}\right.$ of $\mathrm{CuCl}_{2} \cdot 2 \mathrm{H}_{2} \mathrm{O}$ corresponding to $58 \mu \mathrm{mol} \mathrm{L}^{-1}$ of $\left.\mathrm{Cu}^{2+}\right)$. Hence, an acidic medium seemed to be more appropriate to prevent copper cathode dissolution. However, the use of $10^{-2} \mathrm{M}$ phosphoric acid as supporting electrolyte also led to a final alkaline $\mathrm{pH}(\mathrm{pH} 10)$. The presence of high phosphorus concentrations in water bodies such as lakes and rivers is considered as a major cause of eutrophication [1]. For this reason, in order to acidify the supporting electrolyte and to solve the problem related to the corrosion of the working electrode 
while keeping in mind possible environmental impact, the same concentration of phosphoric acid $\left(10^{-2} \mathrm{M}\right)$ was kept and sulfuric acid $\left(5.10^{-2} \mathrm{M}\right)$ was added to the electrolyte ( $\mathrm{pH}$ 1.1). This mixture $\left(\mathrm{NO}_{3}^{-} 3 \mathrm{~g} \mathrm{~L}^{-1}+\mathrm{H}_{3} \mathrm{PO}_{4} 10^{-2} \mathrm{M}+\mathrm{H}_{2} \mathrm{SO}_{4} 5.10^{-2} \mathrm{M}\right)$ resulted in a significant improvement in terms of final $\mathrm{pH}$, since the $\mathrm{pH}$ of the outlet effluent remained constant at $\mathrm{pH}$ 1.1. The $\mathrm{pH}$ of the collected effluent was then adjusted to 5.5 using MES buffer for subsequent biohydrogen production.

Analysis of the various nitrogenous by-products after electrolysis showed that neither nitrite $\left(\mathrm{NO}_{2}{ }^{-}\right)$nor nitrous oxide $\left(\mathrm{N}_{2} \mathrm{O}\right)$ was formed. The nitrate reduction to ammonium was therefore quasi quantitative in the acidic solution with a $\% \mathrm{X}_{\mathrm{NH} 4+}$ of $92.5 \%$; a very high ammonium selectivity was also obtained with a $\mathrm{S}_{\mathrm{NH} 4+}$ of $98.8 \%$ (Table 3 ).

\section{Table 3}

As shown in table 3, after $48 \mathrm{~h}$ incubation, higher biohydrogen production as well as ammonium and glucose consumption yields, than those recorded using a synthetic solution of ammonium were achieved, $0.35 \mathrm{~mol} \mathrm{H}_{2} \mathrm{~mol}^{-1}$ glucose consumed, $97 \%$, and 12.3 $\mathrm{gL}^{-1}(82 \%)$, respectively.

However, the final $\mathrm{pH}(3.5)$ and the dominant metabolic pathways (acetic /butyric acids) appeared similar to those obtained in the case of the synthetic ammonium solution for the same initial glucose amount $\left(15 \mathrm{~g} \mathrm{~L}^{-1}\right)$ and initial $\mathrm{pH}$ 5.5. The biogas was free of methane, $\mathrm{H}_{2} \mathrm{~S}$ and $\mathrm{N}_{2} \mathrm{O}$; it comprised only hydrogen and $\mathrm{CO}_{2}$. In comparison to the synthetic $\mathrm{NH}_{4}{ }^{+}$solution, a significant increase of the hydrogen ratio in the biogas should be highlighted, from $25.5 \%$ to $67.7 \%$ (Table 3 ). 
The feasibility of the use, as a substitute for commercial nitrogen source, ammonium solution generated by nitrate electrochemical reduction for biohydrogen production was therefore confirmed. In addition, it was shown that biohydrogen can be produced via aerobic activated sludge. Moreover, this coupled method allows the elimination of high nitrate concentrations with the production of an acceptable amount of hydrogen, decreasing therefore the global cost of the denitrification process.

\section{Conclusion}

This study demonstrates for the first time to our knowledge the feasibility of coupling electrochemical and biological processes to treat nitrate ions $\left(\mathrm{NO}_{3}{ }^{-}\right)$from waters whilst producing biohydrogen. A flow electrochemical process was developed, allowing a selective and quantitative transformation of concentrated nitrate solutions to ammonium. The obtained ammonium solution was used as a nitrogen source to convert anaerobically glucose to $\mathrm{H}_{2}$. In a batch system involving heat-treated aerobic activated sludge at pH 5.5 and initial glucose concentration of $15 \mathrm{~g} \mathrm{~L}^{-1}$, a hydrogen yield of 0.35 mol $\mathrm{H}_{2} \mathrm{~mol}^{-1}$ glucose consumed with total consumption of the produced ammonium were recorded. Acetic/butyric acid fermentation was the dominant fermentative pathway involved in the system.

In summary, an environmentally friendly coupled process where the pollutant, nitrate, was valorized as a nitrogen source to produce an acceptable yield of biohydrogen via an aerobic activated sludge was developed. The optimization of hydrogen production using more adequate inoculum, namely anaerobic activated sludge, is in progress to continue the present work. 


\section{Acknowledgements}

The authors wish to thank the Lebanese Social Association Azm and Saadeh and Campus France for the financial support of this study.

\section{References}

[1] S.R. Carpenter, N.F. Caraco, D.L. Correll, R.W. Howarth, A.N. Sharpley, V.H. Smith, Nonpoint pollution of surface waters with phosphorus and nitrogen, Ecol. Appl. 8 (1998) 559-568.

[2] Y. Wang, J. Qu, R. Wu, P. Lei, The electrocatalytic reduction of nitrate in water on Pd/Sn-modified activated carbon fiber electrode, Water Res. 40 (2006) 12241232.

[3] J. Kim, M.M. Benjamin, Modeling a novel ion exchange process for arsenic and nitrate removal, Water Res. 38 (2004) 2053-2062.

[4] J. Shen, R. He, W. Han, X. Sun, J. Li, L. Wang, Biological denitrification of highnitrate wastewater in a modified anoxic/oxic-membrane bioreactor (A/O-MBR), J. Hazard. Mater. 172 (2009) 595-600.

[5] C. Glass, J. Silverstein, Denitrification kinetics of high nitrate concentration water: pH effect on inhibition and nitrite accumulation, Water Res. 32 (1998) 831839.

[6] L. Foglar, F. Briški, L. Sipos, M. Vuković, High nitrate removal from synthetic wastewater with the mixed bacterial culture, Bioresour. Technol. 96 (2005) 879888.

[7] K. Rajeshwar, J.G. Ibanez, Environmental electrochemistry: Fundamentals and applications in pollution sensors and abatement, Academic Press, 1997. 
[8] M. Dortsiou, G. Kyriacou, Electrochemical reduction of nitrate on bismuth cathodes, J. Electroanal. Chem. 630 (2009) 69-74.

[9] N.A. Salles, F. Fourcade, F. Geneste, D. Floner, A. Amrane, Relevance of an electrochemical process prior to a biological treatment for the removal of an organophosphorous pesticide, phosmet, J. Hazard. Mater. 181 (2010) 617-623.

[10] K. Bouzek, M. Paidar, A. Sadílková, H. Bergmann, Electrochemical reduction of nitrate in weakly alkaline solutions, J. Appl. Electrochem. 31 (2001) 1185-1193.

[11] C.-Y. Chu, L. Tung, C.-Y. Lin, Effect of substrate concentration and pH on biohydrogen production kinetics from food industry wastewater by mixed culture, Int. J. Hydrog. Energy. 38 (2013) 15849-15855.

[12] D. Karadag, A.E. Mäkinen, E. Efimova, J.A. Puhakka, Thermophilic biohydrogen production by an anaerobic heat treated-hot spring culture, Bioresour. Technol. 100 (2009) 5790-5795.

[13] G. Liu, J. Shen, Effects of culture and medium conditions on hydrogen production from starch using anaerobic bacteria, J. Biosci. Bioeng. 98 (2004) 251-256.

[14] S.-E. Oh, S. Van Ginkel, B.E. Logan, The relative effectiveness of pH control and heat treatment for enhancing biohydrogen gas production, Environ. Sci. Technol. 37 (2003) 5186-5190.

[15] Y. Xiao, X. Zhang, M. Zhu, W. Tan, Effect of the culture media optimization, pH and temperature on the biohydrogen production and the hydrogenase activities by Klebsiella pneumoniae ECU-15, Bioresour. Technol. 137 (2013) 9-17.

[16] M.-L. Chong, R.A. Rahim, Y. Shirai, M.A. Hassan, Biohydrogen production by Clostridium butyricum EB6 from palm oil mill effluent, Int. J. Hydrog. Energy. 34 (2009) 764-771. 
[17] M. Morimoto, M. Atsuko, A.A.Y. Atif, M.A. Ngan, A. Fakhru'l-Razi, S.E. Iyuke, et al., Biological production of hydrogen from glucose by natural anaerobic microflora, Int. J. Hydrog. Energy. 29 (2004) 709-713.

[18] H. Yokoi, A. Saitsu, H. Uchida, J. Hirose, S. Hayashi, Y. Takasaki, Microbial hydrogen production from sweet potato starch residue, J. Biosci. Bioeng. 91 (2001) 58-63.

[19] H. Yokoi, T. Ohkawara, J. Hirose, S. Hayashi, Y. Takasaki, Characteristics of hydrogen production by aciduric Enterobacter aerogenes strain HO-39, J. Ferment. Bioeng. 80 (1995) 571-574.

[20] K.-Y. Show, D.-J. Lee, J.-S. Chang, Bioreactor and process design for biohydrogen production, Spec. Issue Biofuels-III Biohydrogen. 102 (2011) 85248533.

[21] P.C. Hallenbeck, Fermentative hydrogen production: principles, progress, and prognosis, Int. J. Hydrog. Energy. 34 (2009) 7379-7389.

[22] M. Momirlan, T. Veziroğlu, Recent directions of world hydrogen production, Renew. Sustain. Energy Rev. 3 (1999) 219-231.

[23] S. Rittmann, C. Herwig, A comprehensive and quantitative review of dark fermentative biohydrogen production, Microb. Cell Factories. 11 (2012) 115.

[24] A.-J. Wang, G.-L. Cao, W.-Z. Liu, Biohydrogen Production from Anaerobic Fermentation, in: Biotechnol. China III Biofuels Bioenergy, Springer, (2012) 143163.

[25] B. Baghchehsaraee, G. Nakhla, D. Karamanev, A. Margaritis, G. Reid, The effect of heat pretreatment temperature on fermentative hydrogen production using mixed cultures, Int. J. Hydrog. Energy. 33 (2008) 4064-4073. 
[26] C. Li, H.H. Fang, Fermentative hydrogen production from wastewater and solid wastes by mixed cultures, Crit. Rev. Environ. Sci. Technol. 37 (2007) 1-39.

[27] C.-C. Chen, J.-H. Wu, C.-H. Lay, B. Sen, J.-S. Chang, Kinetics of hydrogen production from condensed molasses fermentation solubles using sewage sludge in a continuous stirred tank reactor. Sustain, Env. Res. 21 (2011) 117-121.

[28] H.H. Fang, H. Liu, Effect of $\mathrm{pH}$ on hydrogen production from glucose by a mixed culture, Bioresour. Technol. 82 (2002) 87-93.

[29] C.Y. Lin, C.H. Lay, A nutrient formulation for fermentative hydrogen production using anaerobic sewage sludge microflora, Int. J. Hydrog. Energy. 30 (2005) 285292.

[30] C.-Y. Lin, C.H. Lay, Effects of carbonate and phosphate concentrations on hydrogen production using anaerobic sewage sludge microflora, Int. J. Hydrog. Energy. 29 (2004) 275-281.

[31] M. Rivero, R. Solera, M. Perez, Anaerobic mesophilic co-digestion of sewage sludge with glycerol: Enhanced biohydrogen production, Int. J. Hydrog. Energy. 39 (2014) 2481-2488.

[32] S. Venkata Mohan, V. Lalit Babu, P.N. Sarma, Effect of various pretreatment methods on anaerobic mixed microflora to enhance biohydrogen production utilizing dairy wastewater as substrate, Bioresour. Technol. 99 (2008) 59-67.

[33] C.C. Chen, C.Y. Lin, Using sucrose as a substrate in an anaerobic hydrogenproducing reactor, Adv. Environ. Res. 7 (2003) 695-699.

[34] C.C. Chen, C.Y. Lin, Start-up of Anaerobic Hydrogen Producing Reactors Seeded with Sewage Sludge, Acta Biotechnol. 21 (2001) 371-379. 
[35] X. Wang, B. Jin, D. Mulcahy, Impact of carbon and nitrogen sources on hydrogen production by a newly isolated Clostridium butyricum W5, Int. J. Hydrog. Energy. 33 (2008) 4998-5005.

[36] J.P. van der Hoek, P.J. van der Ven, A. Klapwijk, Combined ion exchange/biological denitrification for nitrate removal from ground water under different process conditions, Water Res. 22 (1988) 679-684.

[37] R. Abdallah, F. Geneste, T. Labasque, H. Djelal, F. Fourcade, A. Amrane, et al., Selective and quantitative nitrate electroreduction to ammonium using a porous copper electrode in an electrochemical flow cell, J. Electroanal. Chem. 727 (2014) $148-153$.

[38] J.-M. Fontmorin, F. Fourcade, F. Geneste, D. Floner, S. Huguet, A. Amrane, Combined process for 2,4-Dichlorophenoxyacetic acid treatment-Coupling of an electrochemical system with a biological treatment, Biochem. Eng. J. 70 (2013) $17-22$.

[39] B.E. Logan, S.-E. Oh, I.S. Kim, S. Van Ginkel, Biological Hydrogen Production Measured in Batch Anaerobic Respirometers, Environ. Sci. Technol. 36 (2002) $2530-2535$.

[40] S. Van Ginkel, B.E. Logan, Inhibition of Biohydrogen Production by Undissociated Acetic and Butyric Acids, Environ. Sci. Technol. 39 (2005) 93519356.

[41] M.B. Salerno, W. Park, Y. Zuo, B.E. Logan, Inhibition of biohydrogen production by ammonia, Water Res. 40 (2006) 1167-1172. 
[42] X.M. Guo, E. Trably, E. Latrille, H. Carrère, J.-P. Steyer, Hydrogen production from agricultural waste by dark fermentation: A review, Int. J. Hydrog. Energy. 35 (2010) 10660-10673.

[43] K. Niu, X. Zhang, W.-S. Tan, M.-L. Zhu, Characteristics of fermentative hydrogen production with Klebsiella pneumoniae ECU-15 isolated from anaerobic sewage sludge, Int. J. Hydrog. Energy. 35 (2010) 71-80.

[44] M. Young, N.P. Minton, W.L. Staudenbauer, Recent advances in the genetics of the clostridia, FEMS Microbiol. Lett. 63 (1989) 301-325.

[45] D. Strmčnik, M. Gaberšček, B. Pihlar, D. Kočar, J. Jamnik, Copper Dissolution in Ammonia Solutions: Identification of the Mechanism at Low Overpotentials, J. Electrochem. Soc. 156 (2009) C222-C229.

[46] G. Faúndez, M. Troncoso, P. Navarrete, G. Figueroa, Antimicrobial activity of copper surfaces against suspensions of Salmonella enterica and Campylobacter jejuni, BMC Microbiol. 4 (2004) 19.

[47] A.S. Gordon, L.D. Howell, V. Harwood, Responses of diverse heterotrophic bacteria to elevated copper concentrations, Can. J. Microbiol. 40 (1994) 408-411. 
Fig.1. Flow electrochemical cell used for nitrate electrolysis

Fig.2. SEM microphotographs of copper porous electrode fibers after copper plating: a, $\times 20 ; b, \times 500$.

Fig.3. $\mathrm{H}_{2}$ yield and glucose consumption as a function of the initial glucose concentration at (a) $\mathrm{pH} 5.5$ and (b) $\mathrm{pH}$ 6.2. Error bars are based on duplicate experiments.

Fig.4. Effect of initial $\mathrm{pH}$ and initial glucose concentration on $\mathrm{NH}_{4}{ }^{+}$consumption $\%$ and final $\mathrm{pH}$. Error bars are based on duplicate experiments.

Fig.5. biogas composition as a function of the initial glucose concentration at $\mathrm{pH} 5.5$ and $\mathrm{pH}$ 6.2. Error bars are based on duplicate experiments.

Table 1: Residual acids, solvents and alcohols in solutions produced at $\mathrm{pH} 5.5$ and $\mathrm{pH}$ 6.2. Errors are based on duplicate experiments 


\begin{tabular}{cccccccc}
\hline $\mathbf{p H}$ & $\begin{array}{c}\text { Glucose } \\
\left(\mathbf{g L}^{-1}\right)\end{array}$ & $\begin{array}{c}\text { Acetaldehyde } \\
\left(\mathbf{m g L}^{-1}\right)\end{array}$ & $\begin{array}{c}\text { Ethyl acetate } \\
\left(\mathbf{m g L}^{-1}\right)\end{array}$ & $\begin{array}{c}\text { Ethanol } \\
\left(\mathbf{m g L}^{-1}\right)\end{array}$ & $\begin{array}{c}\text { n-Butanol } \\
\left(\mathbf{m g L}^{-1}\right)\end{array}$ & $\begin{array}{c}\text { acetic acid } \\
\left(\mathbf{m g L}^{-1}\right)\end{array}$ & $\begin{array}{c}\text { Butyric acid } \\
\left(\mathbf{m g L}^{-1}\right)\end{array}$ \\
\hline & $\mathbf{5}$ & $13.9 \pm 0.5$ & $41.4 \pm 1.0$ & $1498.8 \pm 36$ & $0.4 \pm 0.01$ & $151.2 \pm 4.3$ & $41.6 \pm 12$ \\
$\mathbf{5 . 5}$ & $\mathbf{1 5}$ & $31.6 \pm 1.1$ & $1.9 \pm 0.6$ & $745.1 \pm 10$ & $3.6 \pm 1.5$ & $511.6 \pm 24$ & $96 \pm 18$ \\
& $\mathbf{1 0}$ & $1.6 \pm 0.2$ & $2.6 \pm 0.1$ & $35.1 \pm 3.0$ & $4.9 \pm 1.2$ & $1465.4 \pm 20.0$ & $467 \pm 30$ \\
& $\mathbf{3 0}$ & $35.4 \pm 3.5$ & $1.7 \pm 0.6$ & $13.9 \pm 8.0$ & $20.6 \pm 1.6$ & $1595.5 \pm 110$ & $737.9 \pm 45$ \\
\hline & $\mathbf{5}$ & $3 \pm 0.2$ & $7 \pm 0.6$ & $544 \pm 15$ & $14 \pm 1.6$ & $31 \pm 6.5$ & $84 \pm 3.0$ \\
$\mathbf{6 . 2}$ & $\mathbf{1 0}$ & $18 \pm 1.2$ & $10 \pm 1.0$ & $934 \pm 9.0$ & $6.2 \pm 0.8$ & $128 \pm 6.0$ & $315 \pm 11$ \\
& $\mathbf{1 5}$ & $41 \pm 3.1$ & $20 \pm 4.0$ & $984 \pm 16$ & $8 \pm 2.0$ & $179 \pm 15$ & $615 \pm 14$ \\
& $\mathbf{2 0}$ & $35 \pm 1.2$ & $8 \pm 1.5$ & $600 \pm 7.0$ & $13,7 \pm 1.9$ & $193 \pm 12$ & $615 \pm 3.5$ \\
& $\mathbf{3 0}$ & $25 \pm 1.9$ & $5 \pm 0.5$ & $456 \pm 13$ & $17.5 \pm 2.5$ & $200 \pm 7.0$ & $754 \pm 6.5$ \\
& & & & & & \\
\hline
\end{tabular}

Table 2: Inhibition of biohydrogen production by acetate buffer $210^{-2} \mathrm{M}$ (Synthetic $\mathrm{NH}_{4}{ }^{+}$solution, inoculum $=4 \mathrm{~g} \mathrm{~L}^{-1}$, initial $\mathrm{pH}=5.5$, initial glucose concentration $5 \mathrm{~g} \mathrm{~L}^{-1}$, incubation time $=48 \mathrm{~h}$ ). Errors are based on duplicate experiments.

\begin{tabular}{cccccc}
\hline $\begin{array}{c}\mathbf{H}_{2} \\
(\mathbf{M})\end{array}$ & $\begin{array}{c}\mathbf{C H}_{4} \\
(\mathbf{M})\end{array}$ & $\begin{array}{c}\mathbf{C O}_{2} \\
(\mathbf{M})\end{array}$ & $\begin{array}{c}\text { Glucose consumption } \\
(\%)\end{array}$ & $\begin{array}{c}\mathbf{N H}_{\mathbf{4}}{ }^{+} \text {consumption } \\
(\%)\end{array}$ & Final pH \\
\hline & & & & $12 \pm 1.2$ & $5.1 \pm 0.05$ \\
0.0 & 0.0 & $6.10^{-6} \pm 10^{-9}$ & $10 \pm 2.3$ & & \\
\hline
\end{tabular}


Table 3: Comparison of the $\mathrm{H}_{2}$ production results between $\mathrm{NH}_{4}{ }^{+}$solutions resulting from $3 \mathrm{gNO}_{3}{ }^{-} \mathrm{L}^{-1}$ electroreduction and synthetic ammonium solution. (Initial $\mathrm{pH}=5.5$, initial glucose concentration $=15 \mathrm{~g} \mathrm{~L}^{-1}$, incubation time $=48 \mathrm{~h}$ ). Errors are based on duplicate experiments.

\begin{tabular}{|c|c|c|c|c|c|c|c|c|}
\hline \multirow[t]{2}{*}{$\begin{array}{l}\text { Nitrogen } \\
\text { source }\end{array}$} & \multirow{2}{*}{$\begin{array}{c}\text { Yield } \\
\left(\mathrm{mol} \mathrm{H}_{2}\right. \\
\text { mol }^{-1} \text { glucose } \\
\text { consumed })\end{array}$} & \multirow[t]{2}{*}{$\begin{array}{c}\text { Glucose } \\
\text { consumption } \\
\left(\mathrm{g} \mathrm{L}^{-1}\right)\end{array}$} & \multirow[t]{2}{*}{$\begin{array}{c}\mathrm{NH}_{4}^{+} \\
\text {consumption } \\
(\%)\end{array}$} & \multirow[t]{2}{*}{$\begin{array}{l}\text { Final } \\
\text { pH }\end{array}$} & \multicolumn{2}{|c|}{$\begin{array}{c}\text { Principal } \\
\text { Metabolites } \\
\left(\mathrm{mgL}^{-1}\right)\end{array}$} & \multicolumn{2}{|c|}{$\begin{array}{c}\text { Biogas } \\
\text { composition } \\
(\%)\end{array}$} \\
\hline & & & & & $\begin{array}{l}\text { Acetic } \\
\text { acid }\end{array}$ & $\begin{array}{c}\text { Butyric } \\
\text { acid }\end{array}$ & $\mathbf{H}_{2}$ & $\mathrm{CO}_{2}$ \\
\hline $\mathbf{a}$ & $0.35 \pm 0.01$ & $12.3 \pm 0.5$ & $97.0 \pm 3.5$ & $3.51 \pm 0.1$ & $1610 \pm 53$ & $400 \pm 31$ & $67.7 \pm 3.8$ & $23 \pm 0.3$ \\
\hline b & $0.30 \pm 0.03$ & $8.1 \pm 0.7$ & $53.0 \pm 3.4$ & $3.51 \pm 0.01$ & $1053 \pm 8.0$ & $252 \pm 5.4$ & $24.5 \pm 1.5$ & $75.5 \pm 2.3$ \\
\hline
\end{tabular}

a : Ammonium solution resulting from nitrate electrolysis

$\mathrm{b}$ : Synthetic ammonium solution

\section{Figure 1}




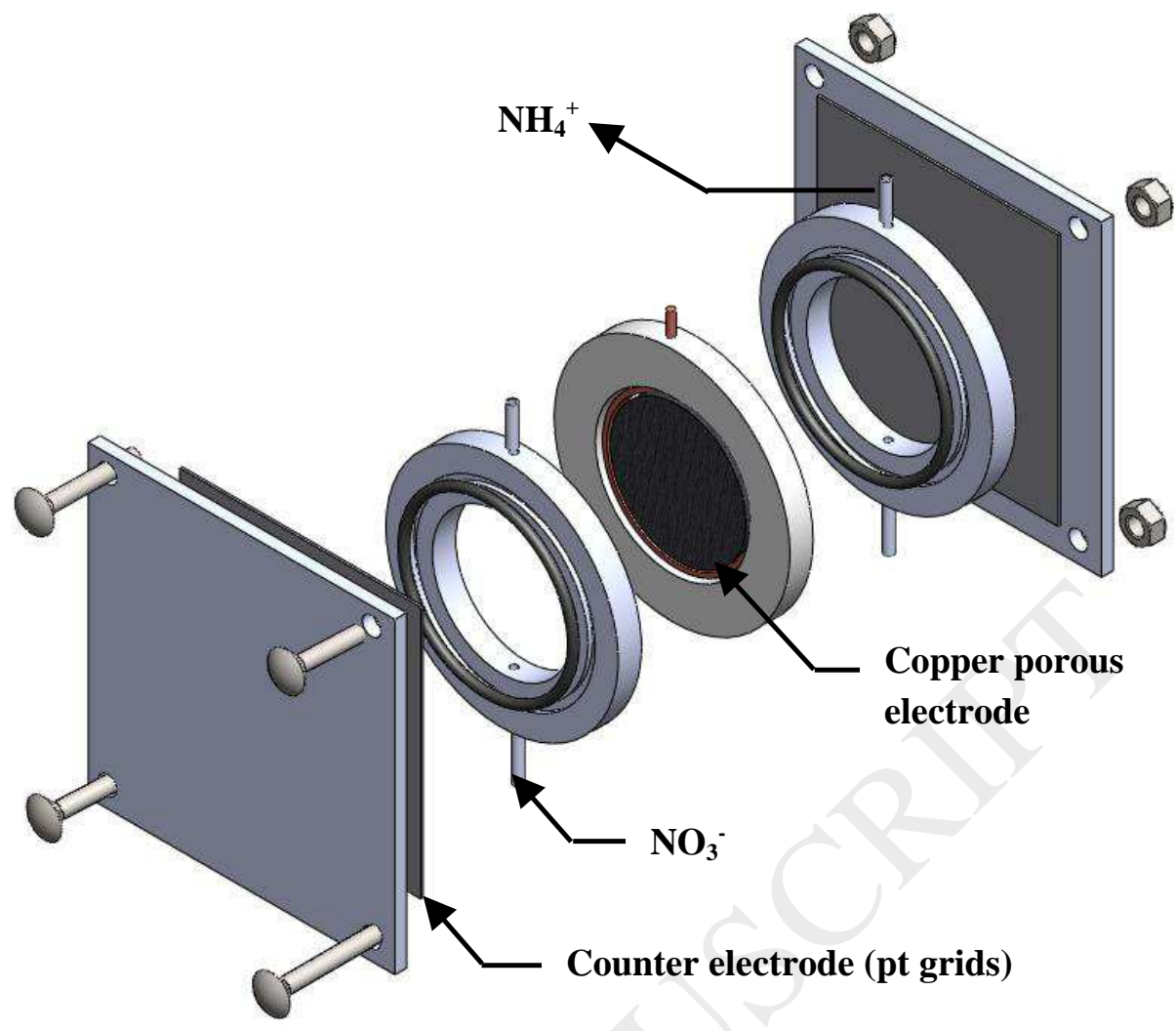

Figure 2
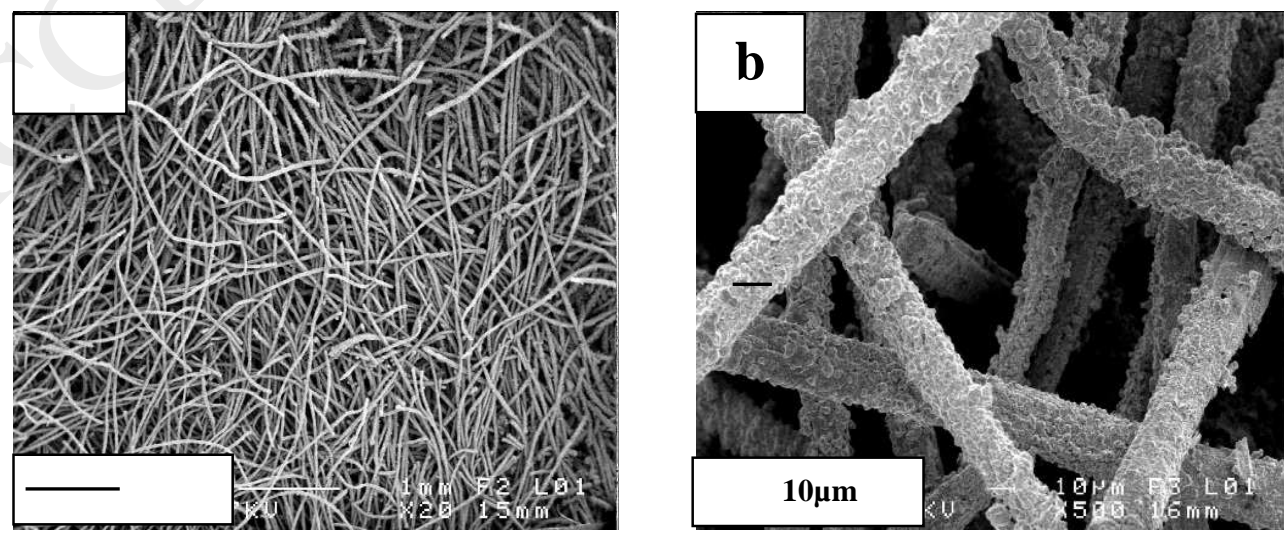
Figure 3

(a)

pH 5.5

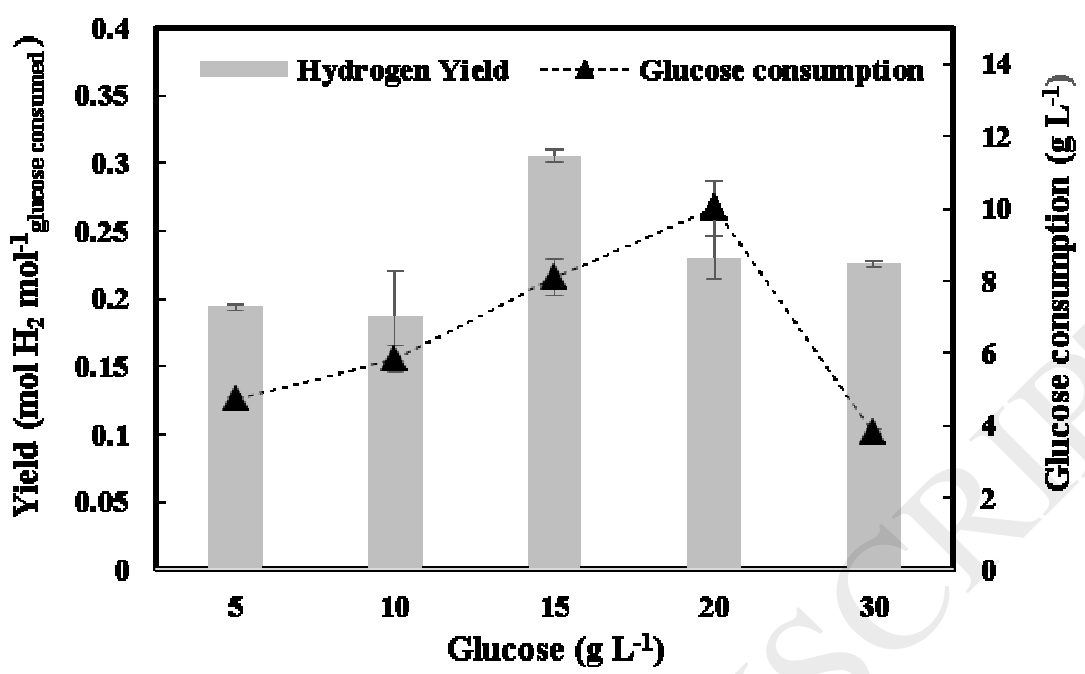

pH 6.2

(b)

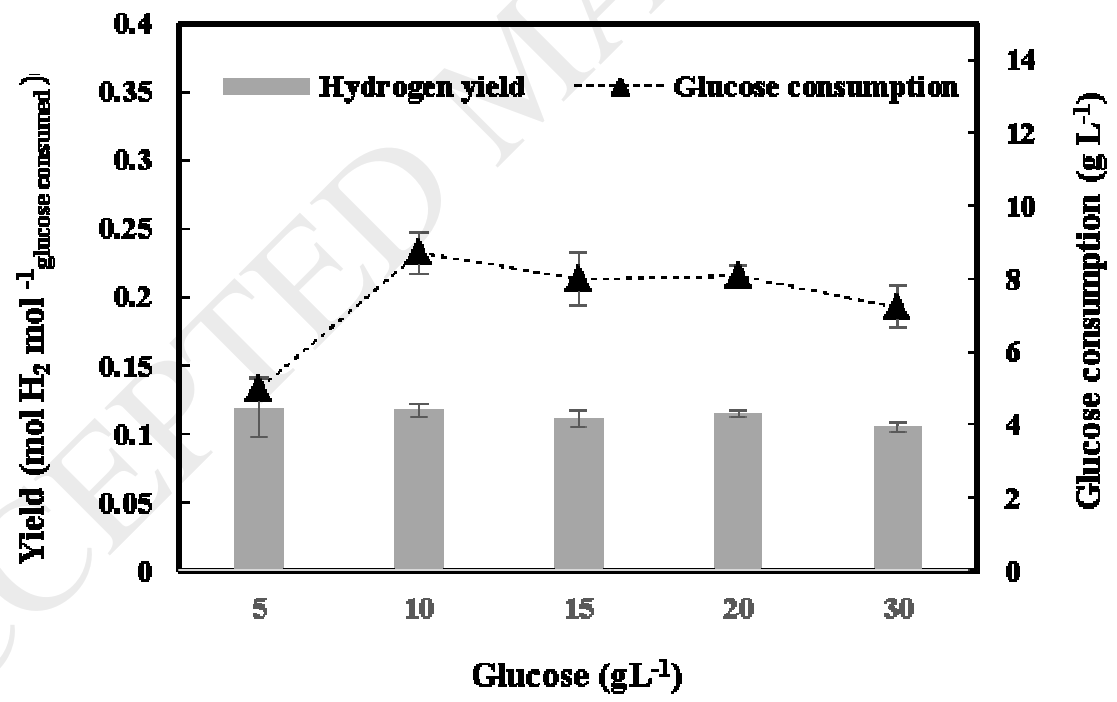

Figure 4 


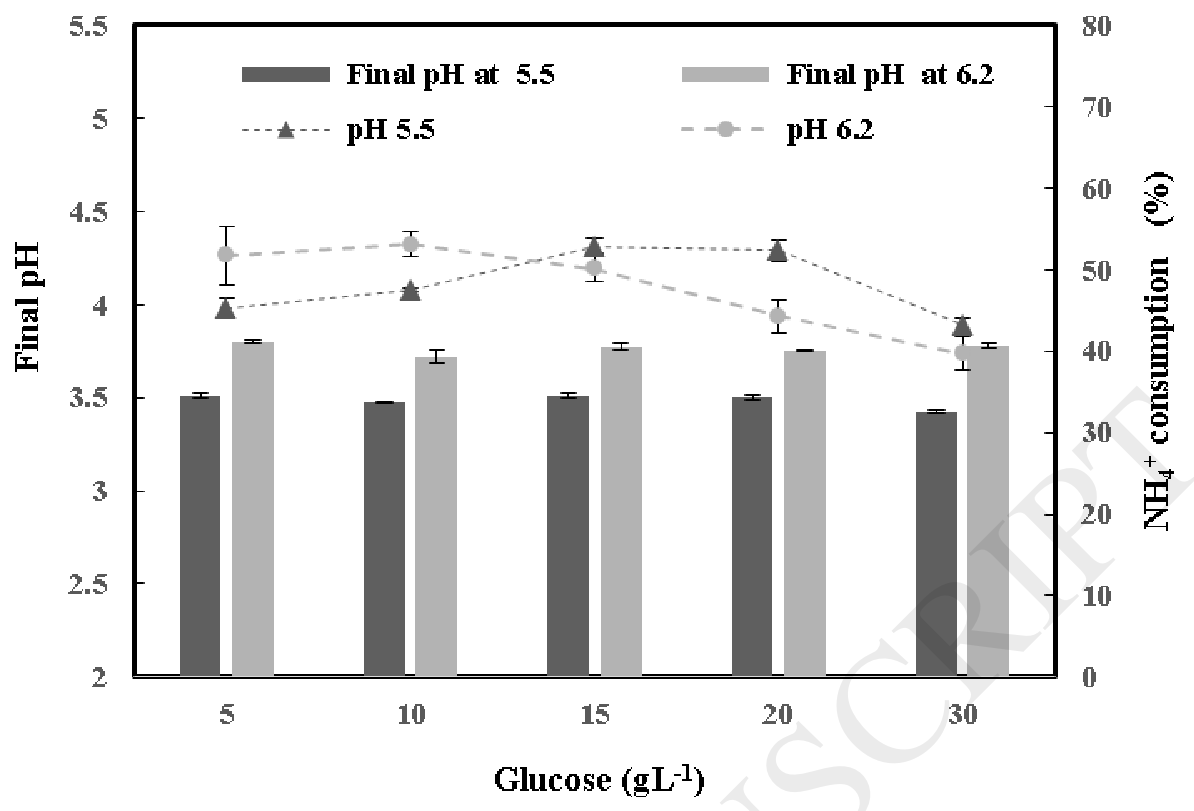

Figure 5 


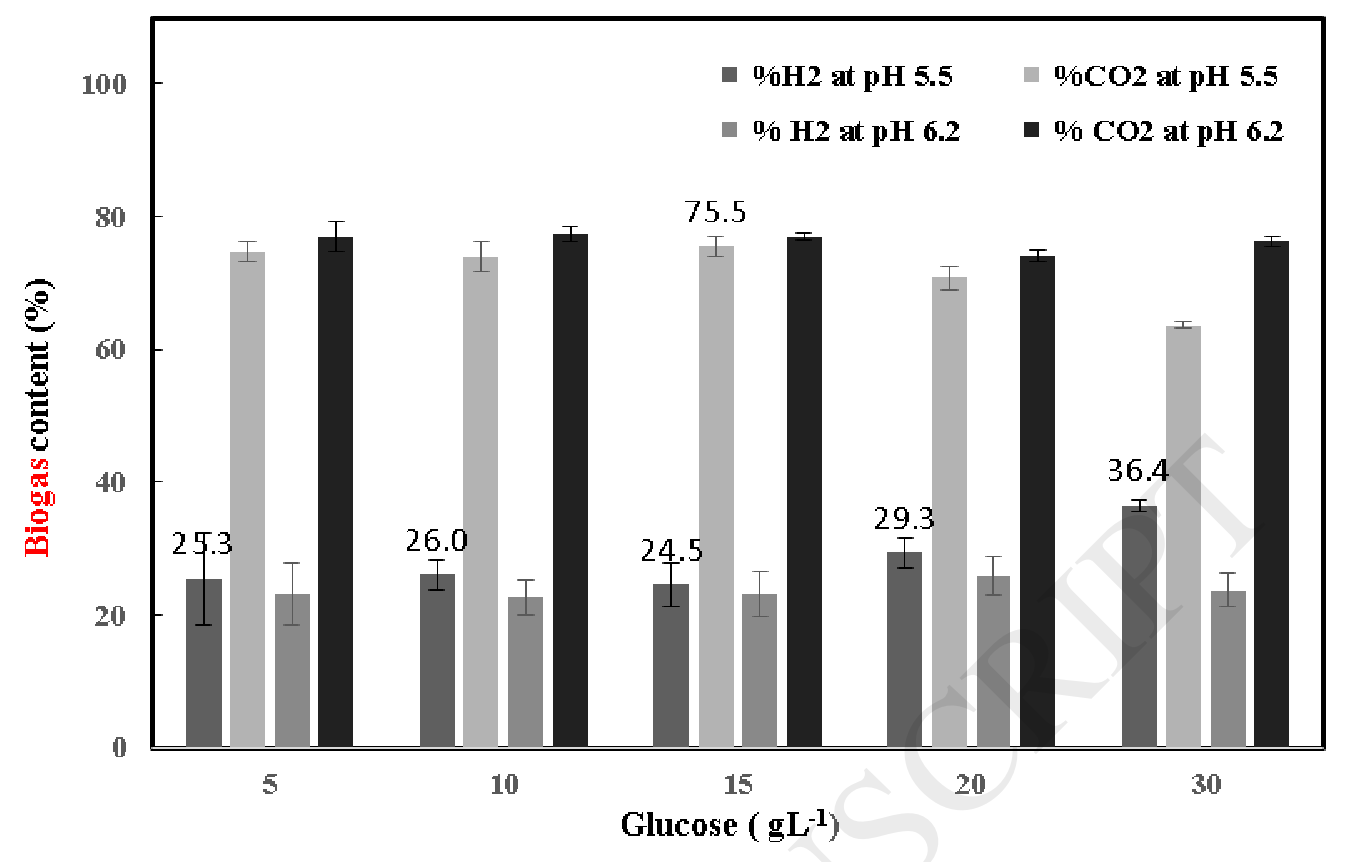

